\title{
Research of Crossing Underneath Construction and the Subway Station Integration Feasibility Analysis
}

\author{
Kewei Ding and Yunhao Feng \\ School of Civil Engineering \\ Anhui Jianzhu University \\ Hefei, P. R. China \\ *Corresponding author
}

\begin{abstract}
Taking the Crossing Underneath construction and the subway engineering as the background, considering the Crossing Underneath construction and the subway station structure located in the upper and lower two layers structure will influence each other, which has caused great difficulties of the excavation of deep foundation pit, using the three-dimensional finite element software to model and established the Mingguang road station numerical analysis, That obtained the structure and deformation of soil data which is consistent with the actual measured structure, as well as conform to the support force of support force and the bending moment value of wall. Using Madis GTS to solve problems of foundation pit finite element analysis established model to comprehensive analyze the mutual influences between construction excavated process in the crossing underneath construction and the subway station.
\end{abstract}

Keywords-subway station; construction phase; supporting structure; numerical model

\section{INTRODUCTION}

In recent 10 years, with the increase of traffic volume in China, the construction of tracks, viaducts, underneath overpasses is getting more and more. It leads to the Integration construction of different kind's traffic channels. This new kind of construction will be groped slowly, and deep foundation treatment is an important part of it.

\section{PROJECT OVERVIEW}

This project is the retaining structure of Hefei metro Line 1 in Mingguang station, which is continuous wall and internal support system, partly is the artificial dig-hole pile. The project is start from $\mathrm{K} 6+179.787$ to $\mathrm{K} 6+448.697$. This station is located in the intersection of Shengli road and Mingguang road. The floor structure of Mingguang station is about 21 to 23.7m.Along Shengli road from south to north. The Shengli road's main road is two-way 6 lanes and the side road is a motor vehicle lane.A crossing underneath will be built at the intersection of Shengli road and Mingguang road along Shengli road. Mingguang road station is set up together with the crossing underneath. The southeast of the station is phase II of the Golden Phoenix Tree Residence which is being constructed, phase I of the Golden Phoenix Tree is a 30-storey Commercial residential, Hefei Hotel, (the clear distance of station foundation pit is about $15 \mathrm{~m}$ ). Northeast corner is lower layers, multilayer shops and residences. Low layers, multi layer at the northwest have already been found out. North part of the station is abandoned Huainan railway. Many pipelines are buried under Mingguang road station. [1]

\section{FINITE ELEMENT NUMERICAL SIMULATION}

In this paper, the Hefei metro line 1 in Mingguang road station deep foundation is simulated by the FEM software[2] Midas GTS. Compare the simulation date with the finally actual monitoring data to confirm the reasonable and stable of the structure.

\section{A. Model Overview}

The deepest point of the station floor is about $19 \mathrm{~m}$, located at strong rock layer, choose $1 \mathrm{~m}$ thick underground continuous wall as the principal part maintenance structure of the station, which is $30 \mathrm{~m}$ deep. 6 braces are set during construction (The first line is $1 \mathrm{~m} * 1 \mathrm{~m}$, The The fifth line are $\$ 609$ steel braces).Since the underground water in excavation of foundation pit area is quite deep, the influence of underground water to model is neglected [3].

\section{B. Hydrogeological Conditions in the Field Engineering}

TABLE I. MINGGUANG ROAD STATION SOIL MAIN PHYSICAL AND MECHANICAL PROPERTIES

\begin{tabular}{|c|c|c|c|}
\hline \multirow{2}{*}{ Layer number } & moisture & specific weight & void ratio \\
\cline { 2 - 4 } & $\boldsymbol{W ( \% )}$ & $\gamma\left(\mathbf{k N / \mathbf { m } ^ { 3 } )}\right.$ & $\boldsymbol{e}$ \\
\hline embankment(1)1 & & $\mathbf{1 7 . 5}$ & \\
\hline clay(2) & $\mathbf{2 3 . 7}$ & $\mathbf{2 0}$ & $\mathbf{0 . 6 9 2}$ \\
\hline silty clay(2)1 & $\mathbf{2 1 . 5}$ & $\mathbf{2 0}$ & $\mathbf{0 . 6 4 2}$ \\
\hline silt(2)2 & $\mathbf{2 0 . 2}$ & $\mathbf{2 0 . 3}$ & $\mathbf{0 . 5 9 8}$ \\
\hline fine sand(2)3 & & $\mathbf{2 0 . 5}$ & $\mathbf{0 . 5 5}$ \\
\hline fine sand(4)3 & & $\mathbf{2 1}$ & $\mathbf{0 . 5}$ \\
\hline $\begin{array}{c}\text { strongly weathered } \\
\text { muddy sandstone(5)1 }\end{array}$ & & 21.5 & $\mathbf{0 . 4}$ \\
\hline $\begin{array}{c}\text { Weathered muddy } \\
\text { sandstone(5)2 }\end{array}$ & & 21 & \\
\hline
\end{tabular}

\section{Foundation Pit Monitoring Content and Analysis}

Aiming at MingGuang road station engineering, Detection mainly include: horizontal displacement monitoring, inclination monitoring, settlement monitoring, supporting axial force monitoring, water lever monitoring, cracks monitoring, structures tilt monitoring,pipe deformation monitoring. 


\section{Midas gts Model Simplified Parameters}

Cross-section diagram and floor plan of foundation pit monitoring sites (Figure. I)

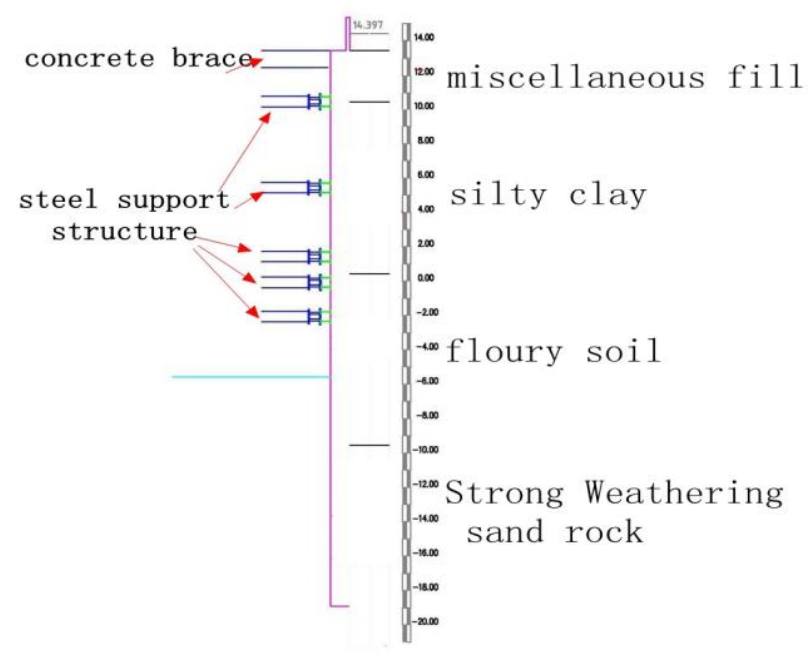

FIGURE I. SUPPORT SECTION

TABLE II. MINGGUANG ROAD STATION ON THE PHYSICAL AND MECHANICAL PROPERTIES OF FOUNDATION PIT SOIL PARAMETERS

\begin{tabular}{|l|l|l|l|l|l|l|}
\hline $\begin{array}{l}\text { Layer } \\
\text { number }\end{array}$ & $\begin{array}{l}\text { eleva } \\
\text { tion }\end{array}$ & $\begin{array}{l}\text { thick } \\
\text { ness }\end{array}$ & $\begin{array}{l}\text { weig } \\
\text { ht }\end{array}$ & $\begin{array}{l}\text { Poisso } \\
\text { n ratio }\end{array}$ & $\begin{array}{l}\text { Cohesive } \\
\text { strength }\end{array}$ & $\begin{array}{l}\text { Modules of } \\
\text { elasticity }\end{array}$ \\
\hline $\begin{array}{l}\text { embank } \\
\text { ment }\end{array}$ & 10 & 10 & 18.5 & 0.4 & 10 & 18.5 \\
\hline silty clay & 0 & 10 & 19.8 & 0.4 & 10 & 19.8 \\
\hline silt & -10 & 12 & 21 & 0.3 & 12 & 21 \\
\hline $\begin{array}{l}\text { strongly } \\
\text { weathere } \\
\text { d muddy } \\
\text { sandston } \\
\text { e }\end{array}$ & -35 & 13 & 21 & 0.3 & 13 & 21 \\
\hline
\end{tabular}

E. This Article Is That the Foundations of the Underground Diaphragm Wall Structure Analysis, in order to Facilitate Calculation Made the Following Assumptions [4]

Assume that the section of the soil in the foundation pit structure is the plane.

Assume that the soil is to be isotropic body.

Support structure has certain elasticity stiffness bar.

Keep close contact between soil and underground diaphragm wall.

Due to the underground water level of the foundation pit excavation area is deep, so that can be ignored the influence of groundwater on buildings in simulation model. The whole simulation all sides and bottom of the unit cell by soil constraints, each additional unit body gravity constraint.

Set the friction contact between the continuous wall and the soil. Model size is 123 meters long and 50 meters wide, 70 meters high, excavation width is 23 meters, 19 meters high, this paper selected the instance of the foundation pit is rectangular plane, finally gains a total of 54121 units. Network partitioning as shown in figure.

The finite element meshing shown in the figure below, The soil unit type is set to eight nodes three-dimensional entity units, shown in the below Fig II.

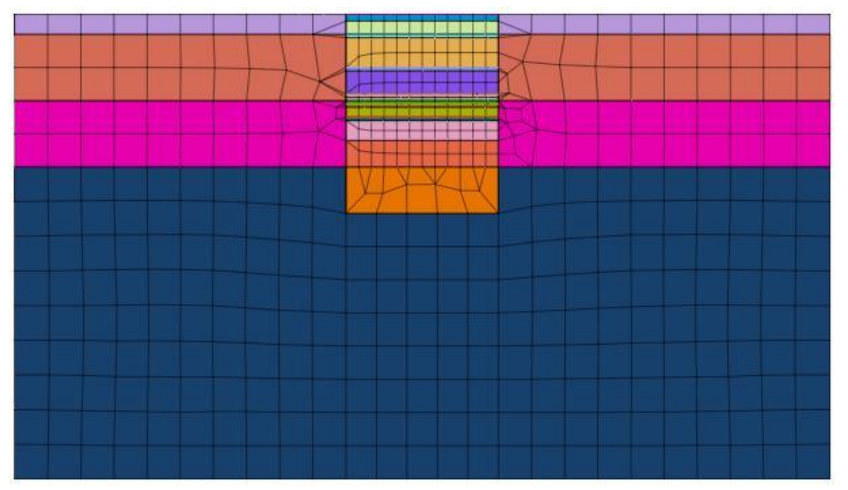

FIGURE II. FINITE ELEMENT MESHING DIAGRAM

\section{F. Define the Construction Stage}

TABLE III. STAGE OF MINGGUANG ROAD STATION EXCAVATION

\begin{tabular}{|c|c|c|c|}
\hline $\begin{array}{l}\text { Working Condition } \\
\text { number }\end{array}$ & $\begin{array}{c}\text { Working } \\
\text { condition type }\end{array}$ & $\operatorname{Depth}(m)$ & Support number \\
\hline \multirow[t]{2}{*}{1} & Excavation & 1 & \multirow{2}{*}{1} \\
\hline & Add Bracing & 0.5 & \\
\hline \multirow[t]{2}{*}{2} & Excavation & 3.5 & \multirow{2}{*}{2} \\
\hline & Add Bracing & 3 & \\
\hline \multirow[t]{2}{*}{3} & Excavation & 8.5 & \multirow{2}{*}{3} \\
\hline & Add Bracing & 8 & \\
\hline \multirow[t]{2}{*}{4} & Excavation & 12.5 & \multirow{2}{*}{4} \\
\hline & Add Bracing & 12 & \\
\hline \multirow[t]{2}{*}{5} & Excavation & 14 & \multirow{2}{*}{5} \\
\hline & Add Bracing & 13.5 & \\
\hline \multirow[t]{2}{*}{6} & Excavation & 16 & \multirow{2}{*}{6} \\
\hline & Add Bracing & 15.5 & \\
\hline 7 & Excavation & 19 & 7 \\
\hline
\end{tabular}

G. The Finite Element Numerical Simulation Analysis

TABLE IV. THE DESIGN CALCULATION IN MINGGUANG ROAD MONITORING PROJECT

\begin{tabular}{|c|c|c|}
\hline $\begin{array}{c}\text { Serial } \\
\text { number }\end{array}$ & Monitoring program & $\begin{array}{c}\text { tolerance index for design } \\
\text { Aggregate-value }\end{array}$ \\
\hline 1 & $\begin{array}{c}\text { Top horizontal } \\
\text { displacement of retaining } \\
\text { structures }\end{array}$ & $30 \mathrm{~mm}$ \\
\hline 2 & $\begin{array}{c}\text { Retaining structure at the } \\
\text { top of the vertical } \\
\text { displacement }\end{array}$ & $10 \mathrm{~mm}$ \\
\hline 3 & $\begin{array}{c}\text { Soil lateral deformation } \\
\text { Brace force }\end{array}$ & Axial force design values \\
\hline 4 & $\begin{array}{c}\text { Supported reinforced } \\
\text { concrete axial force }\end{array}$ & $338.51(-371.18) \mathrm{KN}$ \\
\hline 5 & $\begin{array}{c}\text { the second steel strut } \\
\text { axial force }\end{array}$ & $2794.21 \mathrm{KN}$ \\
\hline 6 & $\begin{array}{c}\text { The third steel strut axial } \\
\text { forces }\end{array}$ & $5054 \mathrm{KN}$ \\
\hline
\end{tabular}




\section{H. The Results of Numerical Simulation and the Design Value Compared to Measured Value}

At the end of excavation, the top horizontal displacement of retaining structures, shown in the figure below. [5]

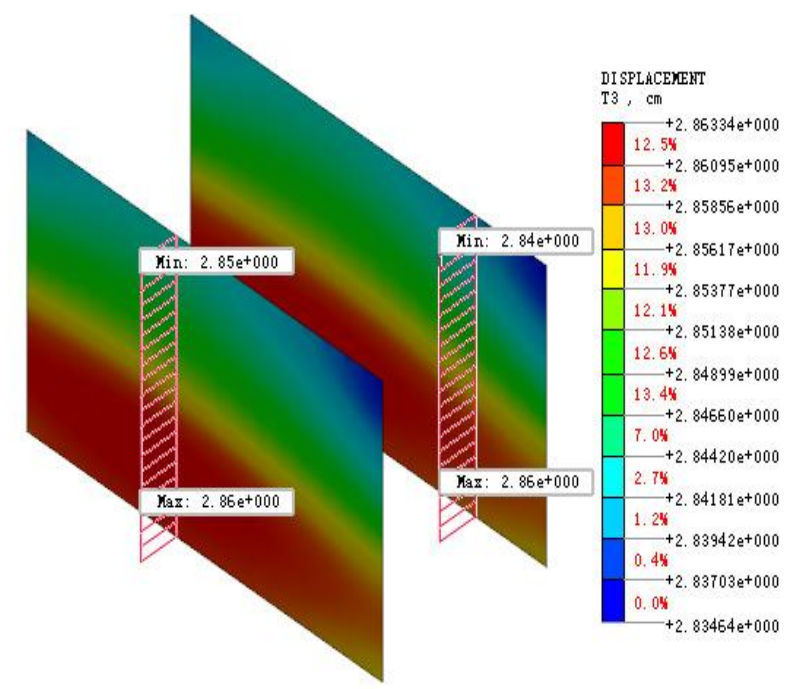

FIGURE III. MADIS SIMULATION DISPLACEMENT OF FOUNDATION PIT EXCAVATION MAINTENANCE

Each phase of excavation retaining structure deformation at the top.

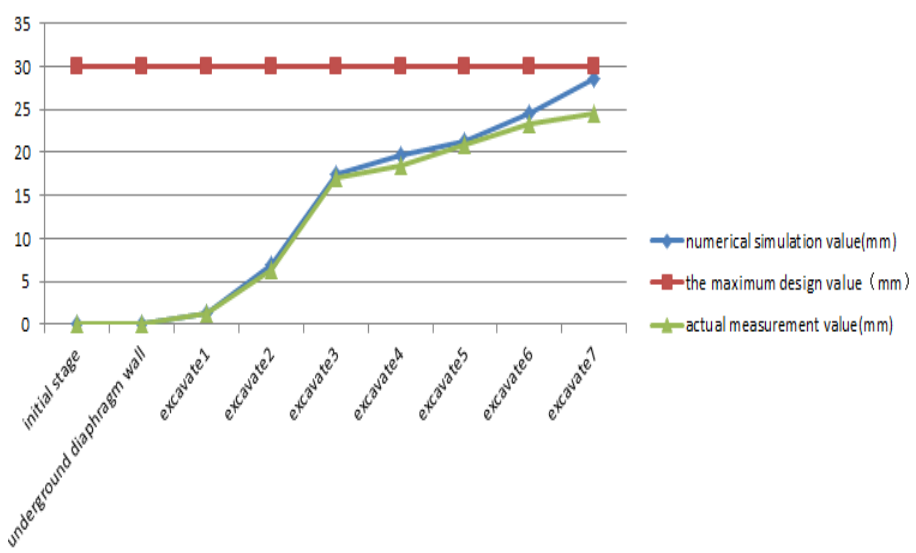

FIGURE IV. THE TOP DESIGN OF STRUCTURE DEFORMATION DESIGN, MEASUREMENT AND NUMERICAL VALUE CONTRAST FIGURE

I Shown in the figure III, IV, it is obvious that the accumulative deformation value is less than $30 \mathrm{~mm}$. Through the simulation of top horizontal displacement and the estimated value, we can straightforward know that with the increase of excavation depth of foundation pit[6] the top of the structure deformation degree is more and more big, the first deformation degree is bigger, finally become tend to ease. $\mathrm{n}$ American English, commas, semi-/colons, periods, question and exclamation marks are located within quotation marks only when a complete thought or name is cited, such as a title or full quotation. [7] When quotation marks are used, instead of a bold or italic typeface, to highlight a word or phrase, punctuation should appear outside of the quotation marks. A parenthetical phrase or statement at the end of a sentence is punctuated outside of the closing parenthesis (like this). (A parenthetical sentence is punctuated within the parentheses.) [8]

Retaining structure at the top of the vertical displacement.

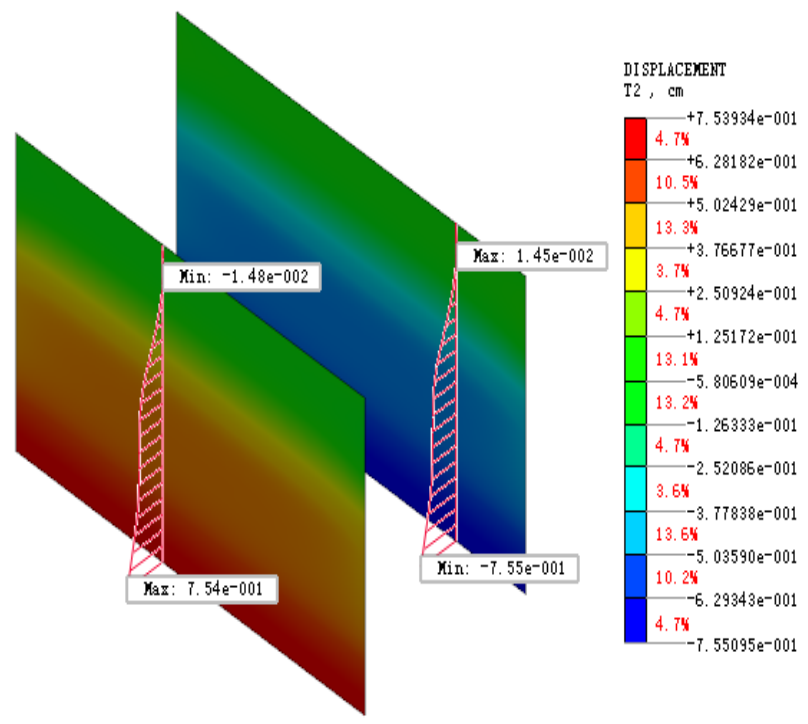

FIGURE V. RETAINING STRUCTURE AT THE TOP OF THE VERTICAL DISPLACEMENT DIAGRAM

Shown in the figure V, It can be seen that satisfy the palisade structure at the top of the vertical displacement of 10 $\mathrm{mm}$.

Each phase of the foundation pit excavation of soil lateral deformation.

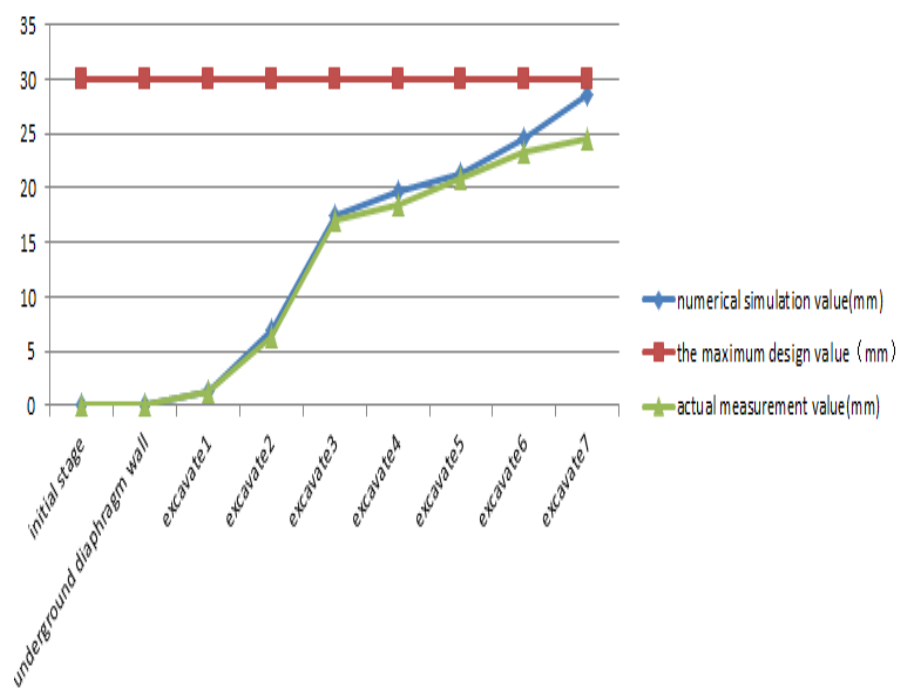

FIGURE VI. THE LATERAL DEFORMATION OF SOIL DESIGN, ACTUAL MEASUREMENT AND NUMERICAL SIMULATION VALUE CONTRAST FIGURE

Through (figure VI) simulation of top horizontal displacement of soil as well as the estimated value, we can see that with the increase of excavation depth of foundation pit on top of the structure deformation degree is more and more big, the first deformation degree is bigger, the finally into easing.

Profile direction stress screenshots. 


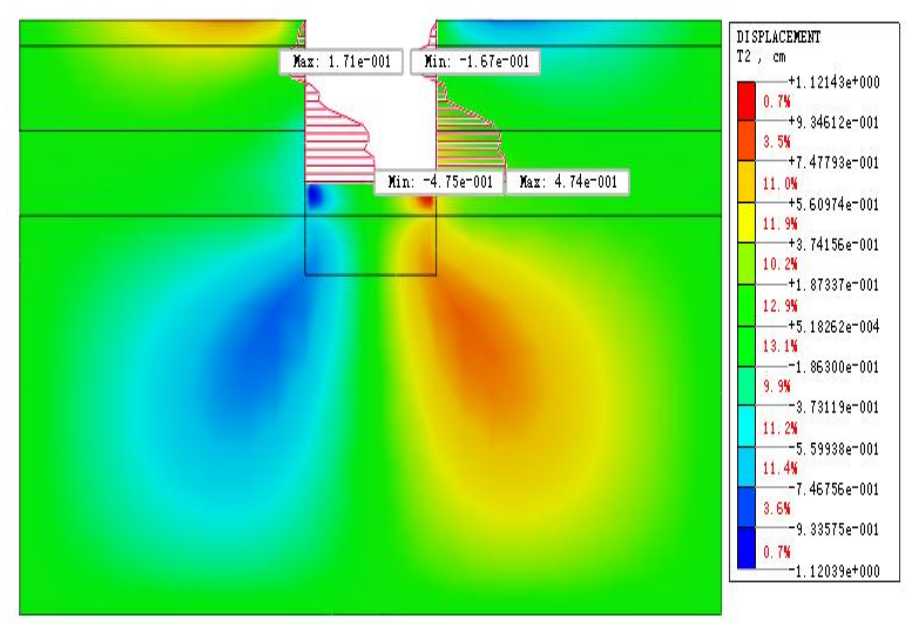

FIGURE VII. PROFILE DIRECTION STRESS SCREENSHOTS

Shown in the figure IX that can be seen it is satisfy the soil deformation is less than $30 \mathrm{~mm}$.

Reinforced concrete brace.

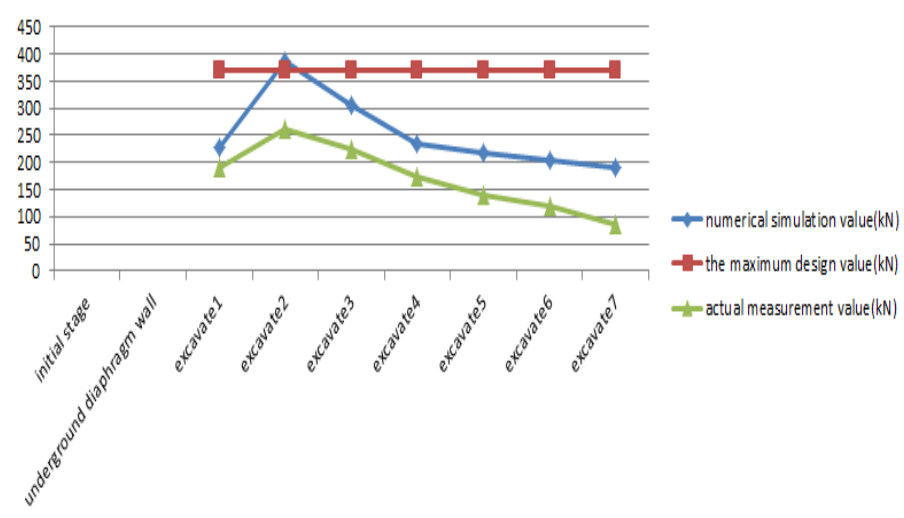

FIGURE VIII. CONCRETE STRUT AXIAL FORCES DESIGN,
MEASUREMENT AND NUMERICAL SIMULATION VALUES
CONTRAST FIGURE

Shown in the figure (figure VII, VIII) concrete supporting in the first step excavation time obviously increased rapidly[9], as the excavation depth, the following steel support after reinforcement, the stress of the concrete support more and more small. The maximum stress of concrete support by numerical simulation is $384 \mathrm{kn} / \mathrm{m}$, and the measured value is $259 \mathrm{kn} / \mathrm{m}$. [10]

\section{CONCLUSION}

Based on MingGuang Road in Hefei subway station foundation pit excavation as a research background, this paper aimed at every stage of the foundation pit excavation to model and analysis of the situation by using the finite element [10] software Midas GTS, numerical simulation analysis of research methods, the conclusions are as follows:

For main control of structure deformation is the deformation in top underground diaphragm wall, the entire process of the excavation deformation of the top will be more and more big [11].

In the process of foundation pit excavation construction need to take some protection measures, for example, in the process of foundation pit excavation need slow excavation, attention the foundation pit and underground diaphragm wall deformation around; in the case of deformation monitoring data become larger can be appropriate for reinforcing the soil.

Soil structure is complicated, a lot of data cannot be measured, only relying on the theoretical analysis and numerical simulation can't completely analyze the working condition and accurate predict [12]. So, in construction process, must strictly comply with the requirements of the design, analysis of monitoring data in time, if it contain any questions should be timely report to avoid affect overall safety.

\section{ACKNOWLEDGMENT}

This project 11472005 supported by National Natural Science Foundation of China and Anhui Provincial Science and Technology Research Project Funding through grant No.1501041133.

\section{REFERENCES}

[1] Hefei metro Line 1 in Mingguang station design, Beijing urban construction design \& research institute co. LTD.2013J. Clerk Maxwell, A Treatise on Electricity and Magnetism, 3rd ed., vol. 2. Oxford: Clarendon, 1892, pp.68-73.

[2] Kewei DING, Xuexue TONG, Numerical Simulation Analysis of the Influence of Underground Pipeline by Shield Construction, Proceedings of 2014 International Conference on Mechanics and Civil Engineering, Vol.7,pp.618-623.

[3] Kewei Ding, Dawei Man, Numerical analysis of Hefei metro shield tunnel construction crossing pile foundation of building, Civil Engineering and Urban Planning - Mohammadian, Goulias, Cicek, Wang \& Maraveas (Eds), 2014 Taylor \& Francis Group, London.

[4] Kikuchi A.,Kawai T.,Suzuki N.. The rigid bodies-spring models and their applications to three-dimensional crack problems [J]. COMPUTER \& STRCTURES, 1992,44:469-480.

[5] V. Silvestri, Ashok K Ckugh, Lateral Earth Pressure Problem of Cohesive Back kill with Inclined Surface[J]. Journal of Geotechnical and Geoenvironmental Engineering, 1996, 122(6):863-873.

[6] Wang K.Y., Elastic-Plastic Consolidation Analysis for Strutted Excavation in Clay[J].Computer and Geotechnics, 1989, 18:348-365

[7] Ayed E. O. Pore Pressure Dissipation during Excavation[J]. Journal of Geotech, ASCE, 1997, 4:523-538.

[8] Erxiang Song ,A nonlinear three-dimensional finite element analysis of deep foundation pit supporting field.V01.25 No.4:538-544, 2004.

[9] Yunian Lu. Analysis and performance deformation and internal-force of retaining and bracing system of super-large deep excavaion combined with substructure of main building [J]. Chinese Journal of Geotechnical Engineering.

[10] Weici Gu, Retaining wall earth pressure calculation [M]. China building industry press, Beijing, 2001.

[11] Hehua Zhu,Zixin Zhang,Shaoming Liao,Underground Structures [M]. China Architecture \& Building Press, Beijing, 2005

[12] Jihong Bi,Hui Wang, Engineering Elasticity and Plasticity [M]. Tianjin university press. 